\title{
IMPLEMENTATION OF THE STRATEGY CARD IN THE SYSTEM OF MILITARY EDUCATION
}

\author{
Venelin Terziev ${ }^{1}$, Marin Georgiev ${ }^{2}$, Nikolay Nichev ${ }^{3}$, Denis Solovev ${ }^{4}$, Plamen \\ Bogdanov ${ }^{5}$
}

${ }^{1}$ Full Member of the Russian Academy of Natural History, Professor, Eng., D.Sc. (National Security), D.Sc. (Economics), D.Sc. (Social Activities), Ph.D. Russian Academy of Natural History, Moscow, Russia, Vasil Levski National Military University, Veliko Tarnovo, Bulgaria, University of

Rousse, Rousse, Bulgaria, terziev@skmat.com

${ }^{2}$ Ph.D, Kaneff University Hospital, Rousse, Bulgaria, clementon@abv.bg

${ }^{3}$ Professor, Ph.D., National Military University, Veliko Tarnovo, Bulgaria, nicheff@abv.bg

${ }^{4}$ Professor, Ph.D., Far Eastern Federal University (FEFU), Vladivostok, Russian Federation, solovev.db@dvfu.ru

${ }^{5}$ Ph.D, University of Library Studies and Information Technologies (ULSIT), Sofia, Bulgaria, bogdanovpn@abv.bg

\begin{abstract}
The aim of this study is to gather sufficient evidence and arguments in order to prove to society that during the process of change in thinking and especially of effective practical implementation of management models such as the balanced scorecard model, high levels of efficiency can be achieved on all hierarchical levels in systems key for the society and the state. It explores opportunities for the model to be successfully adapted to and implemented in the Bulgarian military and educational system.
\end{abstract}

Keywords: balanced scorecards, strategic card, performance measurement, strategic management, control.

\section{INTRODUCTION}

The starting point in developing a strategy BS (Balanced Scorecard) for the senior management level of the organizational hierarchy is the preliminary coordination and unification of positions, regarding the perspective of observing the specific characteristics of the industry and the role of the particular organization. Hence, the need the senior management to have sufficient time to organize and analyze the information needed and to come to reasoned opinion on the issue.

The problem with deformation of the information flow comes on the agenda at the very first moment of compilation of starting information database. Underestimating the organization's advantages that it would receive, if a real and objective picture of the processes inside and around the organization were created, managers would take away all priorities of competitiveness in market life. This is often connected to the confidential nature of the specialized information, both at organizational and institutional level (Terziev, 
Georgiev, 2017).

The senior management are usually unaware of the magnitude of the issues to be solved, so it is vital more specialists to have access to an information database of such nature. The access to information is of particular importance due to the fact that this process essentially influences the attitude of the staff towards the assigned and forthcoming work. Personnel's behavior is based on a value system and a scale of criteria that form assessment, based on past experience (Terziev, Stoyanov, Georgiev, 2017a-b; Petrova, 2019).

The process of developing a strategy card appears to be a particular form of intervention and change of thinking. The transformation of thinking and changing the attitude to work modifies the process of creating a BS into a self-regulating process with a strong cumulative effect. "Everyone who is familiar with the organization's life knows that there are numerous control systems that affect daily activities. However, there is a lack of a systematic understanding of why and how these systems are used as a means of achieving specific programs" (Simons, 1995). By organizing their management system based on the structure of BS, managers can achieve their main objective - putting the strategy into action (Deming, 1985).

When organizations make the key transition to turning their strategic vision into action, they become aware of the real progress and gain a real advantage from developing and implementing a BS. The results of the originally developed BS always lead to a series of management processes that mobilize and reorient organizational efforts.

The development of a starting BS at an organization is achieved through systematic processes that create consensus and clarify how the mission and strategy of the business unit can be aligned with a system of operational objectives and indicators. This starting project needs an architect who should build the structure, make sense of the process, and gather the basic information needed to create such a system. Moreover, a BS must express the collective ideas and energy of the senior management of that organization. If this management team is not fully involved in the process, a successful outcome cannot be achieved. Without the energetic support and involvement of the senior management, a Balanced scorecard project cannot be launched. Without their commitment and interest in the organization, it would be doomed to failure.

The first step of creating an effective BS is to reach consensus and support for the objectives for which the system will be developed. However, the ideological appeal of BS is not a sufficient reason to start such a project. When the process is started, the senior management must determine and achieve an agreement on the principle processes required for the project. The program objectives will contribute for:

- Setting the objectives and indicators for BS;

- Engaging project participants;

- Clear vision of the framework of the system implementation and management processes that should follow the creation of the original BS.

In conclusion, the starting impulse for the implementation of a BS creation project may arise from the need for:

- Clarity and consensus between the vision and strategy of the organization;

- Creation of management experience;

- Clarification and communication of the strategy;

- Setting the strategy objectives;

- Binding of the remuneration with strategy and objectives;

- Unification of strategic initiatives and resources;

- Provision of investments in models and assets;

- Creation of a foundation for strategic knowledge.

Once consensus on the objectives and future role of BS is reached, the organization should focus on identifying who will be its architect or project leader. The architect is responsible for maintaining the structure, philosophy, methodology of BS design and development.

"The architect's role in this process is to provide guidance, to control the schedule of meetings, interviews and seminars, to check the availability of the necessary documentation, baseline data and overall to control the implementation of the process within deadlines and within specific limits" (Kaplan, Norton, 1996). The architect must manage both the cognitive, analytical process and the interpersonal, even emotionally marked 
process while creating a conflict resolution team.

Experience in the comprehension and implementation of the idea of BS in the practice of Kaplan and Norton shows that senior administrative staff of organizations are usually involved in the role of architects. Systemic practice for organizations is to use external consultants to assist the internal architect in the BS development process.

Each organization is unique in itself and may wish to follow its own path of creating a BS. In this work a universal, typical and systematic plan for developing a BS is described, one that has been used by dozens of organizations and that reflects Kaplan and Norton's views on the issue. This position is justified by the scientific opinion that the prototype of Kaplan and Norton's balanced scorecards is considered as an established standard and a classic example of the model.

\section{PROPOSAL FOR A BALANCED SCORECARD MODEL FOR MILITARY UNIVERSITY STRUCTURE}

Short summary of the object of implementation: Vasil Levski National Military University was established in 1878. On September 1, 1878 in Plovdiv, the Russian emperor's commissioner for Bulgaria, adjutant general prince Aleksandar Dondukov, signed a Decree No. 14 on the Military Management of the Bulgarian Army, on the basis of which he appointed the first command staff of the Sofia Military School. The school is called Sofia and is planned to be located in the city of the prince.

Capt. N. Fleischer was appointed First Chief of School. The Decree No. 1 issued on the occasion of the beginning of school's educational activity marks the beginning of the Bulgarian military education system.

In the period 1900-1910, a military high school was operating at the school. The students there are called "cadets" and in addition to general secondary education they also get military training. Subsequently, they enrolled in the military school and continued their education as junkers (student military officers).

After the announcement of the general demobilization of the army after the wars, it resumes its operation from 1 August. Classes began in December 1913, which is one year and three months after they were interrupted (Table 1).

Table 1. Organizational structure of Vasil Levski National Military University.

\begin{tabular}{|c|c|}
\hline \multicolumn{2}{|c|}{ Vasil Levski National Military University } \\
\hline Management & Professional Sergeant College \\
\hline Lecturers (academic community) & $\begin{array}{c}\text { Staff Training Center for Peacekeeping } \\
\text { Operations and Experience Research }\end{array}$ \\
\hline Institute for Research and Innovation & Distance Learning Center \\
\hline & $\begin{array}{c}\text { Formations to provide the learning } \\
\text { process and logistics }\end{array}$ \\
\hline
\end{tabular}

\section{REASONS FOR THE PROPOSAL TO INTRODUCE A STRATEGY CARD IN A MILITARY UNIVERSITY STRUCTURE}

Firstly. The tracked chronology of historical facts and the place the school occupies in the system of defense and security of the Republic of Bulgaria form the opinion that if a strategy for development and improvement is not implemented, it will be difficult to fulfill the stated mission and satisfy the public and partnership needs in the areas of defense, security and peacekeeping. Finding a balance between the public interests and the work of the higher education institution would create opportunities for both parties to bring their positions together as closely as possible and to join forces towards common objectives.

Secondly. The growing expectations towards the education system as a whole, and in particular towards its military education unit, reasonably predetermined by the dynamics of social development, create prerequisites for change and reform to be approached in a systematic and organized manner. It is in this context that the proposal to construct a model of strategic indicator system would enable the management of the process of introducing adequate changes to ignore the negative trends and demographic problems to acquire the characteristics of a controlled and highly effective process. 
The features that make the process of prerequisite analysis and create obstacles to the use of "good practices" can be pointed out in several directions:

- Although there are examples of application of the balanced scorecard model in areas other than material production, problems arise with the modeling of adequate indicators and areas that cover their nature completely (Stoyanov, 2007);

- Due to the differences in the human psychology of human resources, the perception of the model and teamwork creates problems in the process of adaptation and application of examples from foreign experience (Butler, Letza, Neale, 1997);

- Combining the learning process and the specifics of the defense and security system change the structure of the interested parties and reasonably state other content of the internal processes (Goldenberg, Hoffecker, 1994);

- Legislative differences based on the specifics of social conditions make the implementation of good practices in areas such as education difficult to apply without making significant adjustments (Ruddle, Feeny, 1995a).

As a basis for the development of a conceptual model, a sample strategy card is set out, typologically presented in Table 2 (Kaplan, Norton, 2004).

A practical application is registered with the US General Education System. Specific information about working with the scorecard model is available in university systems in the USA, UK, China and other countries (Kaplan, Norton, 1996a).

The analysis of the proposed sample strategy card model reveals that its structure includes six perspectives: objectives and achievements, interested parties, training and administration processes, lecturers training and development, development and work of administrative staff and financial efficiency.

The example is interesting and illustrative because with the first Perspectives "Objectives and Achievements" included, the leading social objectives of the entire education system are represented by objectives related to student achievements, materializing mastery of curricula and shaping the competitiveness of knowledge at national level. This is precisely what conveys the strategic character of the model card indicated.

Table 2. Strategy card of a military education institution

\begin{tabular}{|c|c|c|c|c|}
\hline $\begin{array}{c}\text { Objectives and } \\
\text { achievements. }\end{array}$ & \multicolumn{2}{|c|}{$\begin{array}{c}\text { Mastering of knowledge and } \\
\text { professional habits }\end{array}$} & \multicolumn{2}{|c|}{$\begin{array}{c}\text { Competitiveness of knowledge at } \\
\text { national level }\end{array}$} \\
\hline $\begin{array}{c}\text { Involvement and } \\
\text { satisfaction of clients and } \\
\text { interested parties }\end{array}$ & $\begin{array}{c}\text { Creating a safe } \\
\text { and productive } \\
\text { atmosphere }\end{array}$ & $\begin{array}{c}\text { Parental involvement } \\
\text { and satisfaction }\end{array}$ & $\begin{array}{c}\text { Public participation and } \\
\text { positive attitude towards } \\
\text { the activities of the } \\
\text { University }\end{array}$ \\
\hline $\begin{array}{c}\text { Effective and efficient } \\
\text { training and administration } \\
\text { processes }\end{array}$ & $\begin{array}{c}\text { Effectiveness of the } \\
\text { education }\end{array}$ & $\begin{array}{c}\text { Transport and } \\
\text { meals }\end{array}$ & $\begin{array}{c}\text { Safe and } \\
\text { maintained } \\
\text { premises and } \\
\text { equipment }\end{array}$ & $\begin{array}{c}\text { Readiness for } \\
\text { the new school } \\
\text { year }\end{array}$ \\
\hline $\begin{array}{c}\text { Training and development } \\
\text { of teaching staff }\end{array}$ & Competence of the teaching staff & $\begin{array}{c}\text { Satisfaction of the teaching } \\
\text { staff }\end{array}$ \\
\hline $\begin{array}{c}\text { Development and work of } \\
\text { the administrative staff }\end{array}$ & Competence of the administrative \\
staff
\end{tabular}

Another level of the strategy card covers a set of objectives that seek to approximate the objectives of the students and the demands of the community. For this reason, the generic name "Interested parties and customers" was also found.

Objectives structured in the next level provide information on how the education system and the particular organization deliver the value of the product that society expects and consumes. 
There are quite a few examples where the next two directions (perspectives) of teaching and administrative staff are presented summarized. Experience has shown that their differentiation provides information in greater detail, which makes it possible to evaluate as objectively as possible the place and role, as well as the individual contribution of each to the whole learning process.

Following the classic construction technology and the instructions of the Kaplan and Norton model founders, the strategy card is based on the 'Finance' perspective. It can be argued that with the imposition of a policy of institutional and financial autonomy, its role becomes fundamental and crucial for the success of the governance model alone, as well as for the future of the educational institution.

Summarizing the practices of applying a balanced scorecard in education, project managers and consultants note that "the system is making meaningful progress in improving student achievement and organizational effectiveness" (Playn, 2003).

The starting point for creating a reasoned proposal, constructing a balanced scorecard, covering the work of Vasil Levski National Military University can be considered in two directions.

One is connected to the analysis of already existing practices.

The other one derives from the possibility of the object itself being examined, analyzed to a degree convenient for structuring a card. In this context, the official data make it possible to conclude that:

The organization has a stated mission and purpose that creates an opportunity for a structured vision and the organization itself proves that it has a strongly strategic orientation.

As part of the defense and security system, the university conducts its activities in a very regular and lawful manner.

The analysis of the methodologies used in the work of the university show that there is an institutional attitude to use feedback in order to obtain and accumulate systematically processed data, and periodically to discuss the obtained results. Moreover, adequate software programs are implemented for processing of survey data.

Hence, the stated mission of Vasil Levski National Military University is to form its graduates morally, mentally and physically, to integrate them into the ideals of patriotism, duty and honor, to form them as individuals and leaders with established leadership qualities capable of developing and applying scientific knowledge, managing public and special structures in peacetime and crises, and participating in national and multinational projects to maintain security, protect peace and develop society.

The purpose of the University is to train highly qualified officers and specialists with higher education who are capable of performing active cognitive and research activities and who possess knowledge and skills to manage human and material resources.

Based on this, an exemplary vision can be created according to which Vasil Levski National Military University can see itself in the future as a leader among the higher education institutions in the Republic of Bulgaria, providing students training and research in the field of defense, security and management of processes related to their development and improvement.

An analysis of the stated mission, purpose and a formulated vision indicate that the university would make several key social engagements.

Firstly. Vasil Levski National Military University as a higher education institution, is called upon to form highly educated individuals capable of helping society build a more perfect and humane world. This requires the following:

- The University should support the overall moral and intellectual development of its students and develop their potential and system of moral values in the broadest sense, forming high standards for innovative thinking and professional growth in the new world of knowledge and information;

- The University should provide its students with the knowledge and skills to creatively and professionally solve the problems of the present and the future in the field of defense and security through the acquisition of a balanced complex of classical and contemporary academic disciplines and on the basis of the latest achievements in science;

- The university should develop the opportunities for its students to understand the advantages and disadvantages of the surrounding world, on this basis to form their value system and thus to choose with confidence their present life position for the preservation of truth and freedom in the name of the common good of today's and future generations and the human rights of all individuals; 
- The University should support the motivation of its students to continue their lifelong education, to provide them and all interested citizens with opportunities for continuing education, updating their knowledge and skills in accordance with the needs of today`s society, guaranteed by the effective operation of the national defense and security system.

The abovementioned statements form the conclusion that Vasil Levski National Military University serves its students and sees them as the focus of their existence and key to the future. The diploma awarded to them and the military ranks serve as certification for the successful accomplishment of its mission.

Secondly. The National Military University as a higher education institution is responsible for maintaining and developing a highly erudite academic staff of distinguished national and internationally recognized professors, scientists and specialists. This means that:

- Vasil Levski National Military University supports the efforts of its academic staff in the development and enrichment of educational programs with excellent achievements in knowledge from all over the world and which is in maximum accordance with the needs of the society, observing the world trends with the Bulgarian achievements and university tradition;

- The University develops the opportunities for its academic staff for innovative partnerships with business, public administration and the international academic community in order to create conditions for the development and dissemination of intellectual research products contributing to the continuous improvement of the system of defense and social security, guaranteeing sustainable social development;

- The university encourages and sets high standards for creative development of its academic staff, creating an environment of mutual commitment to individual scientific development and evaluating the benefits of a rich diversity of people and ideas, united by mutual trust and desire to serve the university and tolerant and pluralistic academic community;

- The University creates adequate conditions for the promotion of the prestige and authority of the members of its academic staff as individuals with significant and unique contribution to the social development, both in the field of science and defense and security, providing that the work of everyone is assessed fairly.

The abovementioned statements on the academic staff show that Vasil Levski National Military University considers its staff as its most valuable asset and regards its preservation and development as the highest guarantee for its future in the name of its students and the strengthening of the defense and security system of Bulgaria/the education system of the Republic of Bulgaria.

Thirdly. Vasil Levski National Military University is called upon to establish and improve itself as a respected and valued territory of the national educational and research area. This is interpreted as:

- The university should uphold its academic autonomy and institutional integrity and take them as a basis in maintaining high standards for intellectual and professional development. As a guarantee for this, systems for management and quality assurance of the educational process have been set up in accordance with the leading European standards and good practices, thus setting high objectives for its development and creating an environment of high morale and responsibility, corresponding to the expectations stated by the society in terms of defense and security;

- The University should support and organize contacts and cooperation of its academic staff, cadets and administration with leading Bulgarian and foreign universities, purposefully analyze the positive experience and apply it in a timely manner in order to actively participate in the development of ideas and events that improve the national and the European Defense and Security System;

- Vasil Levski National Military University should develop its library and all its information and material and technical facilities, striving for the highest possible standards and achieving full synchronization with the advancement of information and communication technologies;

- The university should maintain a sufficiently qualified administrative staff dedicated to serving the university and fulfilling its mission, to support and encourage the development of its knowledge and skills in the management of management systems.

From the last sentences it can be summed up that, based on its good long-standing traditions, the National Military University is obliged to continuously enrich and consolidate its image as a dynamically developing, modern national educational and research institution, deliberately committed to the functioning and future of the defense and security system. 
Overall, the full and competitive integration of Vasil Levski National Military University into the educational and research space poses a huge challenge. The possible and fully feasible vision of the university to gain a leadership position among the higher education institutions in Bulgaria working in the field of defense and security is testing the university community, requiring full commitment and dedication of the whole staff. Of particular importance for the accomplishment of the stated mission and the possible vision of the University is the current period during which the prerequisites and the achieved irreversibility in the tendencies to achieve highly competitive positions on a national scale ensuring the effective functioning of the defense and security system/military education system.

The factual analysis, the regulatory framework with the expected changes and the results achieved, viewed as prerequisites for the application of the conceptual model of the balanced scorecard, form the view that the model / strategy card / BS as a concept is applicable to the needs of the university. However, it would be appropriate that such opportunities are considered through some details.

Firstly. Restructuring of the Bulgarian army and the adaptation of personnel to the new conditions completed by the end of 2015.

Secondly. The changed needs of the community related to the work of the national security and defense system.

Thirdly. Expected changes for the development of the academic staff, predetermined by the unification of the criterion system for the evaluation of the performance of scientific and educational systems.

Fourthly. Despite the stated mission of the university and the stated purpose, the content of the vision has not been specified, i.e. no university development strategy has been stated and announced. For this reason it would be fragmentary and incomplete to differentiate the indicators and structure the directions related to the strategy.

On these grounds, the possibility of applying the concept of a system of indicators presented in the form of a balanced scorecard may be the basis for the construction of a card related to the creation of a strategic plan for the development of Vasil Levski National Military University.

In the structure of general provisions of the strategic proposal, the following points stand out:

The leading and main objective of this plan is to achieve higher dynamics in the development of Vasil Levski National Military University, ensuring full use of all the opportunities for expression and improvement provided at this stage of social development to secure good starting positions in the national educational and scientific community.

The development of these dynamics sets out to find and highlight key factors for the success of the university and involve the entire academic community in actively engaging in the work of university levers and mechanisms for their effective use.

In defining the key factors for the success of the University, the proposed strategic plan proceeds from an understanding of the paramount importance in satisfying the well-founded claims of major interested parties: cadets, students, the security and defense system, their future employers, the academic and administrative staff and society itself. The key factors of satisfaction are decomposed into operational factors, which are presented as a major part of the university's functioning mechanisms, which determine the strategic indicators relating to the development of the university for the next academic year.

The structure of the strategic plan in terms of its expediency reflects the development of the university and presents it in four key directions (perspectives):

1. Cadets and Students perspective;

2. Academic and administrative staff perspective;

3. Internal University Processes perspective;

4. Material and technical base and finance perspective;

Perspectives of the students and of the academic and administrative staff answer the question of what students should expect and what teachers and administrators need to do in order to obtain a competitive product that fully meets the expectations of the society in general and in particular of the defense and security system/military education system.

Directions of Internal Processes, Material and technical base and finance analyze these university processes, material and technical and financial prerequisites, which play a key role in maximizing the 
satisfaction of the academic community, the defense and security system and the successful development of the university (Terziev, Bogdanova, Kanev, Georgiev, 2019a).

The modeling of each direction (perspective) takes into account well-established views on the development of the European education and research area, as well as the national objectives and requirements set out above all in the texts of the Higher Education Act, the Act for the development of the Academic Staff in the Republic of Bulgaria and the latest criteria required by the new socio-economic conditions.

The technological implementation of a strategic plan is connected to decomposing the factors and university performance indicators into units and determining the specific commitments of the units and their staff to achieve them. The technological solution itself provides for a broad and democratic discussion of the objectives and results achieved and the search for alternatives for more effective future development. This is precisely what implies initiating and bringing the plan in accordance with what has been achieved and with changes in the social environment. At the same time, it is envisaged to carry out comparative studies on the activity and results of others, especially foreign educational establishments, as well as constant monitoring of the level of compliance of the university activity with the state requirements and public expectations and attitudes (Radev, Mihaylova, Terzieva, Stoyanovich, 2014-a; Mihaylova, 2015; Popov, Aleksandrova, Garov, Mihaylova, 2016; Balkanska, Garov, Trendafilova, Mihaylova, Georgiev, 2017).

\section{CONCLUSION}

Analyzing "good practices" for creating specific conditions and prerequisites, as well as structuring a purposeful model for different parts of the hierarchical structure of the military education system, allows us to draw several generalized conclusions (Petrova, Petrov, 2020-c):

Firstly. Considering high applicability and the concept of the system of indicators and the model of the balanced scorecard itself, they fit as closely and adequately as possible into the nature and organizational specificity of the national defense and security system and in particular the military education system. In its diversity, the conceptual model creates the conditions to increase the efficiency of the processes running throughout the defense and security system and at the same time to organize the achievement of a lasting impact, covering both operations and strategy.

Secondly. The submission of proposals for the implementation of a balanced scorecard builds on the rationally accumulated information from the entire defense and security system. In this way, on the one hand, it transforms institutional thinking as a valuable capital and structures it in a new and adequate to the dynamics of reality model of behavior, and on the other hand, it enhances the importance of the so-called intangible assets in the process of restructuring of the Bulgarian Army. Thus, provided that the size of the system is reduced as a compensatory mechanism with the accumulation of more knowledge and professional skills, the human resources of the security and defense system in the new information and organizational environment are transformed into human capital, which makes the whole army small, but effective enough to accomplish the objectives and objectives set by the state and partners.

Thirdly. The proposals made at the various levels of the institutional hierarchy prove that a more rational and effective management method may be required in the application of the conceptual model based on continuity and upgrading. This would provide the necessary transparency of the objectives and objectives that have been set for the implementation of the whole system and would create conditions for maximum understanding of the problems and optimal involvement in solving them. In reality, this would increase the level of organizational (military) culture and would become the main motive for purposeful and fruitful work.

\section{REFERENCE LIST}

Terziev, V., Georgiev, M. (2017). Highlights of the evolution of the 'Balanced Scorecard' idea as a model for managing strategy development and control. // SOCIOINT 2017- 4th In-ternational Conference on Education, Social Sciences and Humanities 10-12 July 2017- Du-bai, UAE, OCERINT- International Organization Center of Academic Research, Istanbul, Turkey, 2017, pp. 607-610, ISBN: 978-60582433-1-6.

Terziev, V., Stoyanov, E., Georgiev, M. (2017a). The Balanced Scorecard Model as a tool for effective 
management. // Scientific journal «Economics and finance». Editorial Arane, S.A. de C.V. Research: tendencies and prospects, Collection of scientific articles, Mexico City, Mexico, 2017, pp. 239-243, ISBN 978-0-9942661-5-6.

Terziev, V., Stoyanov, E., Georgiev, M. (2017b). The Balanced Scorecard Model as a tool for improvement of the national defense system management. // Scientific journal «Econom-ics and finance». Editorial Arane, S.A. de C.V. Research: tendencies and prospects, Collection of scientific articles, Mexico City, Mexico, 2017, pp. 7-12, ISBN 978-0-9942661-5-6.

Petrova, T. (2019). Modeling Of Temperature Distribution In Biotissues, Proceedings of SOCIOINT 2019-6th International Conference on Education, Social Sciences and Humanities, 24-26 June 2019- Istanbul, Turkey, 2019, pp. 346-353, ISBN 978-605-82433-6-1.

Simons R. (1995). Levers of Control: How Managers Use Innovative Control Systems to Drive Strategic Renewal, Boston: HBS Press, 1995, p.11.

Deming, W. (1985). Out of the crisis, Cambridge: Massachusetts Institute of Technology, 1985.

Kaplan, R., D. Norton. (1996). The BS: Translating Strategy into Action, 1996, Harvard College, p.380.

Stoyanov, E. (2007). Spetsifika na balgarskata problematika pri rabota po balansiranite karti kato instrument za kontrol, sp. Upravlenie i ustoychivo razvitie, br.1-2/2007, str.272. (Стоянов, Е., Специфика на българската проблематика при работа по балансираните карти като инструмент за контрол, сп. Управление и устойчиво развитие, бр.1-2/2007, стр.272).

Butler, A., Letza, S., Neale, B. (1997). Linking the Balanced scorecard to strategy, Long Range Planning, 1997, Vol. 30, №2.

Goldenberg, H., J., Hoffecker. (1994). Using the Balanced Scorecard to develop Companywide Performance Measures, Journal of Cost Management, Fall 1994.

Ruddle, K., D. Feeny. (1995a). Transforming the organization, Oxford Executive, Research Briefings, 10.02.1995.

Kaplan, R., D., Norton. (2004). Strategy cards: Converting Intangible Assetsinto Tangible Outcomes, HBSP Corp., 2004, p.447.

Kaplan, R., D., Norton. (1996a). The Balanced Scorecard: translating strategy into action, N.J., 1996, tail 1.

Playn, Th. (2003). Citizen, 07.02.2003, p.7.

Terziev, V., Bogdanova, M., Kanev, D., Georgiev, M. (2019a). Uses of the strategic card in the Republic of Bulgaria's land forces. // Proceedings of ADVED 2019 - 5th International Conference on Advances in Education and Social Sciences, 21-23 October 2019, Interna-tional Organization Center of Academic Research, Istanbul, Turkey, 2019, pp. 519-525, ISBN: 978-605-82433-7-8.

Radev, E., Tsv., Mihaylova, A., Terzieva, Al., Stoyanovich. (2014). Profesionalizam-profesionalen moral. // „Kontakt 2014“ ot 27 yuni 2014, Sofiya, Izdatelstvo TEMPO-Sofiya, s. 203-206, ISSN 1313-9134 (Радев, Е., Цв., Михайлова, А., Терзиева, Ал., Стоянович. Професионализъм-професионален морал. // „Контакт 2014“ от 27 юни 2014, София, Издателство ТЕМПО-София, с. 203-206, ISSN 1313-9134).

Radev, E., Tsv. Mihaylova, A., Terzieva, Al., Stoyanovich. (2014a). Sotsiologicheski aspekti na zdravniya menidzhmant. // „Kontakt 2014“ ot 27 yuni 2014, Sofiya, Izdatelstvo TEMPO-Sofiya, s. 365-368 ISSN 1313-9134 (Радев, Е., Цв. Михайлова, А. Терзиева, Ал. Стоянович. Социологически аспекти на здравния мениджмънт. // „Контакт 2014“ от 27 юни 2014, София, Издателство ТЕМПО-София, с. 365-368 ISSN 1313-9134).

Mihaylova, Tsv. (2015). Neobhodimosty v lidere i liderskih kachestvah, formay i metoday sotsialynoy rabotay v razlichnayh sferah zhiznedeyatelynosti. // Ulan-Ude, Izdatelystvo VSGUTU, 2015 (Михайлова Цв. Необходимость в лидере и лидерских качествах, фооры и методы социальной работы в различных сфрерах жизнедеятельности. // Улан-Удэ, Издательство ВСГУТУ, 2015).

Popov, T., M., Aleksandrova, Sv., Garov, Tsv., Mihaylova. (2016). Izkustvoto vav vazpitatelnata deynost. // Nauchni statii, Trideset i osma nauchno-tehnologichna sesiya INGA sbornik izd. «TEMTO» Sofiya, 28. 10. 2016, str.9-15 (Попов, Т., М., Александрова, Св., Гаров, Цв., Михайлова. Изкуството във възпитателната дейност. // Научни статии, Тридесет и осма научно-технологична сесия ИНГА сборник изд. «ТЕМТО» София, 28. 10. 2016, стр.9-15). 
Balkanska, P., Sv., Garov, A., Trendafilova, Tsv., Mihaylova, N., Georgiev. (2017). Podhodi za ekipna efektivnost. // 39 Nauchno-tehnologichna sesiya "Grazhdanskata ideya v deystvie” Kontakt 2017, 30 yuni 2017g., Sofiya. Izd. Temto. 199-204 (Балканска, П., Св., Гаров, А., Трендафилова, Цв., Михайлова, Н., Георгиев. Подходи за екипна ефективност. // 39 Научно-технологична сесия „Гражданската идея в действие” Контакт 2017, 30 юни 2017г., София. Изд. Темто. 199-204).

Petrova, T., Petrov, Zh. (2020). Alternative Approaches for Long-Term Defence Planning. // Proceedings of SOCIOINT 2020-7th International Conference on Advances in Education and Social Sciences, 20-22 January, 2020-Dubai, U.A.E., International Organization Center of Academic Research, Istanbul, Turkey, 2020, pp. 818-825, ISBN 978-605-82433-8-5.

Petrova, T., Petrov, Zh. (2020a). Analysis on the Leading Trends and Capabilities of UAV'S and Their Application in the European Cooperation Projects. // Proceedings of SOCIOINT 2020-7th International Conference on Advances in Education and Social Sciences, 20-22 January, 2020-Dubai, U.A.E., International Organization Center of Academic Research, Istanbul, Turkey, 2020, pp. 826-833, ISBN 978-605-82433-8-5.

Petrova, T., Petrov, Zh. (2020b). Economic Factors in the Development and Application of UAV's and the Fight With Wild Fires. // Proceedings of SOCIOINT 2019-7th International Conference on Advances in Education and Social Sciences, 20-22 January, 2020-Dubai, U.A.E., International Organization Center of Academic Research, Istanbul, Turkey, 2020, pp. 811-817, ISBN 978-605-82433-8-5.

Petrova, T., Petrov, Zh. (2020c). Long Term Development Perspectives for UAV Potential. // Proceedings of SOCIOINT 2019-7th International Conference on Advances in Education and Social Sciences, 20-22 January, 2020-Dubai, U.A.E., International Organization Center of Academic Research, Istanbul, Turkey, 2020, pp. 802-810, ISBN 978-605-82433-8-5. 